DOI: $10.30519 /$ ahtr.972877

Advances in Hospitality and Tourism Research (AHTR)

\title{
THAILAND'S IMAGE FROM THE PERSPECTIVES OF CHINESE NON-VISITORS AND VISITORS
}

\author{
Raweewan PROYRUNGROJ ${ }^{1}$ \\ Sol International Hospitality Management (SIHOM), \\ Sol International School, Woosong University, Republic of Korea \\ ORCID: 0000-0002-3904-9827
}

\begin{abstract}
This study examined Chinese non-visitors' and visitors' perceptions of Thailand as an outbound destination. It employed a qualitative approach using semi-structured interviews. Data were gathered from 24 Chinese respondents, of which 12 had visited Thailand and 12 had not. Thematic analysis was undertaken. The findings showed that the perceptions of nonvisitors and visitors were quite different, mainly due to the types of information sources these people used in their destination image formation process. The non-visitors tended to have positive images, whereas the visitors had more mixed perceptions of Thailand.
\end{abstract}

\author{
Article History \\ Received 18 July 2021 \\ Revised 15 November 2021 \\ Accepted 29 November 2021 \\ Published online 24 Dec. 2021 \\ Keywords \\ Thailand \\ destination image \\ Chinese \\ non-visitors \\ visitors \\ perceptions
}

\section{INTRODUCTION}

Many countries around the world have become aware of the need to develop a positive image among their target markets as a way to gain a competitive advantage (Carballo et al., 2015; Magnusson et al., 2014; Qu et al., 2011). Destination image plays a vital role in destination marketing as it helps differentiate a destination from its competitors (Ashworth \& Kavaratzis, 2009; Kavaratzis \& Hatch, 2013; Stylidis \& Cherifi, 2018), thus making places attractive for potential visitors (Kotler \& Gertner, 2002; Papadimitriou et al., 2015). Destination image is also believed to influence visitors' awareness and decision-making processes (Carballo et al., 2015; Perpiña et al., 2019). Existing literature (Alcocer \& Ruiz, 2020; Stylidis et al., 2017; Stylidis \& Cherifi, 2018) agrees that positive destination image

1 Address correspondence to Raweewan PROYRUNGROJ (PhD), Assistant Professor, Sol International Hospitality Management (SIHOM), Sol International School, Woosong University, Republic of Korea. E-mail: raweewan_pr@wsu.ac.kr 
increases peoples' likelihood of visiting that destination and positively affects their on-site experiences. It also positively affects visitors' post-visit behaviours, such as repeat trips, and favourable recommendations of a destination (Ahmad et al., 2020; Hernández-Mogollón et al., 2018), and increased visitors' loyalty (Qu et al., 2011). Therefore, understanding visitors' and potential visitors' perceptions of destination image is pivotal (Ashworth \& Kavaratzis, 2009; Kavaratzis \& Hatch, 2013; Stylidis \& Cherifi, 2018).

Thailand has become increasingly famous as a major international tourism destination. According to the World Tourism Organisation (2019; 2021), Thailand is the eighth most-visited destination by international tourists in 2018 and 2019, receiving 38,277,000 and 39,797,000 tourists, respectively. Among these visitors, many came from China, representing approximately $27.52 \%$ and $27.63 \%$ of the total international tourists visiting Thailand during these periods (National Statistical Office, 2021; World Tourism Organisation, 2019; 2021). Between 2012 and 2019, China has been the top tourist source market for Thailand, with a sharp rise from around 2.79 million in 2012 to almost 11 million in 2019 (National Statistical Office, 2021). In 2019, visitors from mainland China contributed $\$ 17,120$ million to the Thai economy (National Statistical Office, 2021). This huge number of Chinese visitors was the result of the Thai government's ongoing efforts to implement proactive promotional campaigns, the introduction of an exemption for visa-on-arrival fees for Chinese visitors, and intensive marketing campaigns by relevant Thai public and private agencies in China to attract Chinese visitors (Kasikorn Research Center, 2018; 2019). The Kasikorn Research Center (2018) ranked Thailand as the most favourite destination of Chinese visitors in 2018. A close look at the Chinese market is therefore crucial for tourism sector in Thailand, especially the examination on how Chinese visitors and potential visitors perceive Thailand as a tourist destination.

Although there is extensive research on destination image, studies on image of Thailand are still limited, with the majority of studies employing a quantitative approach (e.g. Henkel et al., 2006; Promsivapallop \& Kannaovakun, 2019; Rittichainuwat et al., 2001). Although these studies have contributed to the knowledge on destination image of the country, their findings rely on a predetermined set of destination attributes, developed by the researchers, without allowing respondents to freely name attributes, beliefs, impressions, and feelings that shape their image of Thailand. Tapachai and Waryszak (2000) argue that this approach has limitations in that it forces the respondents to respond to destination 
attributes that may not reflect their perceptions, and that this could lead to inaccurate conclusions.

To gain a more complete picture of Thailand's image in the perceptions of visitors and potential visitors, additional studies using a qualitative approach are therefore needed, providing respondents with the freedom to describe the country based on the attributes they consider relevant, thereby capturing more in-depth insights on this issue, and making a better understanding of the image of Thailand as a tourist destination.

To address this gap in the literature, this study employed a qualitative approach to examine the differences in the perceptions of Chinese non-visitors and visitors on the image of Thailand as a tourist destination. Specifically, it aimed to: (1) explore their perceptions on cognitive (beliefs or knowledge about Thailand's attributes), affective (feelings towards Thailand), and conative dimensions (intentions to visit/revisit Thailand) of Thailand's image, both in positive and negative way, and investigate whether and how differences exist in the perceptions of these two groups; and (2) examine factors influencing their perceptions.

Chinese respondents were selected because, as mentioned, Chinese market represents an important market for inbound tourism of Thailand, and to date, there is very limited research on this topic from the perspectives of Chinese people specifically. Previous research studied the perceptions of a mixed group of international tourists, which might or might not include Chinese respondents. Moreover, perceptions of non-visitors and visitors on Thailand's image also represent a gap in the literature as previous studies on Thailand's destination image focus on the comparison between first-time travellers and repeat travellers (Rittichainuwat et al., 2001) or between international tourists and residents (Henkel et al., 2006). To address these research gaps, this study aimed to compare the perceptions of non-visitors and visitors, which has not yet been done in the context of Thailand's destination image. Such knowledge not only add empirical evidence to the existing literature on destination image of Thailand, but can also help tourism policy-makers, destination planners, and the destination marketing organizations (DMOs) to understand in what ways the perceptions of these two groups are different and what factors contribute to such differences as well as find effective marketing and promotion strategies to attract the visitors to make a repeat visit and the non-visitors to make an actual visit in the near future. 


\section{LITERATURE REVIEW}

\section{Definitions, Components, and Characteristics of Destination Image}

Several definitions of 'destination image' were found in existing literature. Some authors and researchers describe destination image by emphasising only its cognitive aspect, while others recognise the coexistence of cognitive and affective dimensions in the construct of destination image, thereby including the affective dimension. Cognitive dimension of the destination image refers to individual's beliefs or knowledge of the attributes of a tourist destination (Baloglu, 1999; Baloglu \& McCleary, 1999a; Pike \& Ryan, 2004), while the affective component is associated with feelings towards a tourist destination (Baloglu \& McCleary, 1999a; Krider et al., 2010). Many researchers (Agapito et al., 2013; Baloglu \& McCleary, 1999a; Li et al., 2010) also point out that cognitive and affective images are interrelated, and affective images depend on individuals' assessment of their cognitive images.

The examples of the definitions which emphasise only the cognitive image are: Gartner and Hunt (1987) who define tourism image as the impressions that individuals hold about a particular place in which they do not reside; and Echtner and Ritchie (1991) who note that destination image should encompass perceptions of individual attributes (such as weather, transportation, accommodation, and friendliness of local people) as well as more holistic impressions of the place. As for definitions that include both cognitive and affective dimensions of destination image, the widely-cited ones include: Baloglu and McCleary (1999a) defining this concept as an individual's beliefs, knowledge, feelings, and global impression about a destination; and Kim and Richardson (2003) describing this term as a totality of beliefs, impressions, opinions, expectations, and feelings people have and accumulated towards a place over time.

Apart from cognitive and affective components of destination image, many researchers (Afshardoost \& Eshaghi, 2020; Kladou \& Mavragani, 2015; Michael et al., 2018) note that the conation dimension, representing an individual's behaviour, such as his/her intention to visit/revisit a destination and/or recommend it to other people, should also be regarded one of the main components of destination image. Many researchers (Afshardoost \& Eshaghi, 2020; Agapito et al., 2013; Peña et al., 2012) argue that the three components of destination image are hierarchically related, with cognitive and affective images influencing conative images. 
A destination can be perceived positively or negatively (Perpiña et al., 2019), encouraging or discouraging potential visitors to visit a certain destination. Several researchers (Alvarez \& Campo, 2014; Perpiña et al., 2019) argue that negative images are formed based on individuals' perceptions of risks such as crime, terrorism, robberies, diseases, and harassment. Other authors (Reisinger \& Mavondo, 2005; 2006; Quintal et al., 2010) add that perception of risk is closely related to individuals' feelings of uncertainty, fear, worry, and anxiety. In this sense, risk perception can become part of the cognition and affective evaluations of the image of a certain destination.

Regarding destination image's characteristics, the study by Gallarza et al. (2002) contributes by identifying four main features of the destination image including complex, multi-dimensional, relativistic, and dynamic. This argument has been agreed upon by many other researchers (e.g. Chi \& Qu, 2008; Martín \& Rodríguez del Bosque, 2008; Stylidis \& Cherifi, 2018). In terms of complexity, the three aspects of destination image (cognitive, affective, and conative components) play an important role in making this phenomenon complex (Gallarza et al., 2002). As for its multiplicity, many studies (Chi \& Qu, 2008; Glover, 2009; Stylidis \& Cherifi, 2018) reveal that individuals described their destination image of a certain place using a number of attributes (e.g. tourist attractions and activities, natural environment, climate, accessibility, friendliness of the locals and culture) and feelings.

As for the relativistic nature of destination image, existing literature (Smith et al., 2015; Stylidis \& Cherifi, 2018; Tan \& Wu, 2016) found that differences of destination image exist between non-visitors and visitors to a certain destination. For example, Stylidis and Cherifi (2018) report that images of non-visitors to London tend to be vague and simplistic, whereas those of visitors are more specific and concrete. Kotler and Gertner (2002) explain that the vague images held by non-visitors are a result of a lack of concrete images for that given destination, and therefore, they often base their perceptions on stereotypes or simplifications.

As for the dynamic characteristic of destination image, several researchers (Chen, 2019; Kong et al., 2015; Stylidis \& Cherifi, 2018) agree that destination image is not static, but is subject to constant change. These researchers explain that destination image constantly evolves from stereotypes and simplifications to more complex, multi-dimensional images. Chen (2019)'s study, comparing traveller's pre-trip and post-trip perceptions to Macau by collecting data from the same groups of visitors, 
reveals that before visiting Macau, visitors had stereotypical and simple images of Macau, but after the trip, their ideas became more concrete and detailed. They also explain that the dynamic nature of destination image is a result of visitors' assessment of their on-site experiences, gained through their encounter with the place and its people.

\section{Perceptions of Destination Image between Non-Visitors and Visitors}

Several researchers (Riscinto-Kozub \& Childs, 2012; Smith et al., 2015; Tan $\& \mathrm{Wu}, 2016)$ establish that perceptions of destination image of visitors differ from those of non-visitors, generally because visitors tend to have more knowledge of a destination than non-visitors, and therefore can describe more attributes of a destination in detail, whereas non-visitors seem to have general knowledge only of a destination and can speak in broad terms only (Hughes \& Allen, 2008; Song \& Hsu, 2013; Stylidis \& Cherifi, 2018).

Sources of information are found to play a vital role in formulating differences in the perceptions of a destination image between non-visitors and visitors (Baloglu \& McCleary, 1999b). Baloglu and McCleary (1999b) point out that non-visitors form their perceptions based on secondary information such as word-of-mouth, movies, and media, whereas visitors' perceptions of destination image are based on their on-site experiences, including contact with local people and facilities. On-site experiences lead visitors to create a more complex, specific, and differentiated image of the destination than non-visitors (Song \& Hsu, 2013; Stylidis \& Cherifi, 2018).

\section{Factors Influencing Destination Image Formation}

Several studies (e.g. Kim \& Chen, 2016; Pan \& Tsang, 2014; Terzidou et al., 2018) have reported that formation of destination image in the perceptions of individuals is influenced by various factors. Baloglu and McCleary (1999a) pioneered this area by developing a model of destination image formation. Based on their model, destination image is influenced by individuals' factors and stimulus factors. Personal factors include motivations and socio-demographics (i.e. age and education) whereas stimulus factors refer to variety (amount) and type of information sources. They also point out the roles of these factors in influencing each component of the destination image by stating that age, education, and variety (amount), and types of information sources (i.e. word-of-mouth, movies, advertisement, books, news, and professional advice) have an influence on cognitive image, and all of these factors together with motivations influence the affective image of individuals. 
The factors in Baloglu and McCleary's (1999a) model have been studied by others. In relation to motivations, Martín and RodrÍguez del Bosque (2008) and Khan et al. (2017) support Baloglu and McCleary's (1999a) model, arguing that individuals with different motivations tend to have different images of the same destination. Regarding information sources, Stylidis and Cherifi's (2018) study found that the complex images of London hold by visitors are a result of a variety of information sources consulted before visiting, such as word-of-mouth and internet research. Moreover, other studies found that non-visitors' increased interest in a certain destination is influenced by movies, dramas, and documentaries (Kim, 2012; Pan \& Tsang, 2014; Terzidou et al., 2018), travel blogs (Gholamhosseinzadeh et al., 2021), and user-generated content (UGC) (Xu et al., 2021)

In addition, there is common agreement among many researchers (e.g. Konecnik \& Ruzzier, 2006; Smith et al., 2015; Stylidis et al., 2017) that on-site travel experiences also serve as an important factor influencing the formation of the destination image. These researchers note that visiting a destination led visitors to modify their prior knowledge. Such modification is a consequence of several factors, including increased knowledge (Stylidis \& Cherifi, 2018), familiarity (Baloglu, 2001; Stylidis \& Cherifi, 2018), and feeling connected to the place (George \& George, 2004).

\section{METHODOLOGY}

As mentioned above that it has been widely agreed that destination image is complex, multi-dimensional, relativistic, and dynamic, so this phenomenon cannot be sufficiently captured by data gained from a questionnaire comprising a predetermined set of destination attributes (Ryan \& Cave, 2005). In contrast, a qualitative approach allows the respondents to freely describe their knowledge, feelings, and behavioural intention concerning a given destination image, as well as factors influencing their perceptions. Thus, the researcher believed that a qualitative methodology deems appropriate for this study.

Semi-structured interviews were conducted with Chinese nonvisitors and visitors to Thailand. The rationale for employing semistructured interviews lies in their potential to enable the researcher to gather rich data because she could clarify questions to interviewees (Carey, 2013). If the answers given by interviewees are unclear or too brief, this technique allows the researcher to probe for more clarification (Carey, 2013). The interview guide was developed by the researcher based on the 
literature review and was tested for its effectiveness in eliciting all the data needed to fulfill the research objectives during the pilot study (Jennings, 2011).

Table 1. Interview guides used during the pilot study and the main study

\begin{tabular}{|c|c|c|}
\hline $\begin{array}{l}\text { Interview guide (pilot } \\
\text { study) }\end{array}$ & Interview guide (main study) & Reason for revision \\
\hline \multirow[t]{3}{*}{$\begin{array}{l}\text { What do you think about } \\
\text { Thailand? Why? }\end{array}$} & $\begin{array}{l}\text { What images, pictures or } \\
\text { characteristics first come to your } \\
\text { mind when you think of Thailand } \\
\text { as a tourist destination? Why? }\end{array}$ & $\begin{array}{l}\text { The question is too general. } \\
\text { Some respondents answered } \\
\text { this question by thinking of } \\
\text { Thailand in general, not as a } \\
\text { tourist destination. }\end{array}$ \\
\hline & $\begin{array}{l}\text { What factors make you have such } \\
\text { perceptions? }\end{array}$ & $\begin{array}{l}\text { This question was added to } \\
\text { encourage the respondents to } \\
\text { discuss the factors influencing } \\
\text { their perceptions. }\end{array}$ \\
\hline & $\begin{array}{l}\text { Could you please tell me about } \\
\text { your experiences regarding these } \\
\text { perceptions? (for visitors) } \\
\text { Could you please tell me about } \\
\text { your reasons/factors making you } \\
\text { have such perceptions? (for non- } \\
\text { visitors) }\end{array}$ & $\begin{array}{l}\text { These questions were added to } \\
\text { allow the researcher to probe } \\
\text { for deeper details. }\end{array}$ \\
\hline $\begin{array}{l}\text { What do you like most } \\
\text { and least about Thailand? } \\
\text { Why? }\end{array}$ & $\begin{array}{l}\text { What do you like most and least } \\
\text { about Thailand? Why? }\end{array}$ & Unchanged \\
\hline $\begin{array}{l}\text { What are the unique or } \\
\text { distinctive things that you } \\
\text { can think of about } \\
\text { Thailand? Why do you } \\
\text { hold such perceptions? }\end{array}$ & $\begin{array}{l}\text { What are the unique or distinctive } \\
\text { things that you can think of about } \\
\text { Thailand? Why do you hold such } \\
\text { perceptions? }\end{array}$ & Unchanged \\
\hline $\begin{array}{l}\text { How would you describe } \\
\text { your feelings, moods, or } \\
\text { emotions about Thailand? } \\
\text { (for non-visitors) }\end{array}$ & $\begin{array}{l}\text { How would you describe your } \\
\text { feelings, moods, or emotions } \\
\text { about Thailand as a place to visit } \\
\text { or a tourist destination? (for non- } \\
\text { visitors) }\end{array}$ & $\begin{array}{l}\text { This question was revised by } \\
\text { emphasizing Thailand 'as a } \\
\text { place to visit' or 'a tourist } \\
\text { destination' because some } \\
\text { respondents answered this } \\
\text { question by thinking of } \\
\text { Thailand in general, not as a } \\
\text { tourist destination. }\end{array}$ \\
\hline $\begin{array}{l}\text { How did you feel about } \\
\text { Thailand while visiting } \\
\text { the country? (for visitors) }\end{array}$ & $\begin{array}{l}\text { How did you feel about Thailand } \\
\text { while visiting the country? (for } \\
\text { visitors) }\end{array}$ & Unchanged \\
\hline $\begin{array}{l}\text { Do you a plan to } \\
\text { visit/revisit Thailand in } \\
\text { the near future? Why? } \\
\text { Which places do you plan } \\
\text { to visit? }\end{array}$ & $\begin{array}{l}\text { Do you a plan to visit/revisit } \\
\text { Thailand in the near future? } \\
\text { If yes, why, when and which } \\
\text { places do you plan to visit? Why? } \\
\text { If not, why? }\end{array}$ & $\begin{array}{l}\text { The word 'when' was added in } \\
\text { order to gain more information } \\
\text { on the intended behavior of the } \\
\text { respondents. }\end{array}$ \\
\hline
\end{tabular}

A pilot study was carried out with five respondents whom the researcher had personal contact with. Two were non-visitors and the other three had been to Thailand at least once during the past five years. The pilot 
study not only tested the effectiveness of the interview guide, but also allowed the researcher to become familiar with the interview questions (Jennings, 2011). As a result of the pilot study, some questions were found to be ambiguous and were revised, and some questions were added. Table 1 illustrates the questions in the interview guide employed during the pilot study and the revised/added questions from the main study. Some followup questions may also be added based on the stories told by the respondents.

The main study was conducted between June and August 2019. As the researcher was not able to communicate in Chinese, the interviews were conducted either in English or Thai, so only individuals who could speak either of these languages were approached. Twenty-four semi-structured interviews were conducted, including those carried out during the pilot study. This number of respondents was defined by the saturation point of the data, which was when the answers of the respondents became repetitive.

Purposive and snowball sampling were employed to identify and reach interviewees based on the determined criteria which included: (i) being Chinese people who had never visited Thailand or those who had visited the country at least once during the past five years; (ii) being able to communicate in English; and (iii) eighteen years old and above for ethical reasons. Purposive sample was mainly used during the pilot study to identify the first set of the respondents whose qualifications met with the determined criteria and was also used during the main study. According to Patton (2014), the effectiveness of this sampling technique lies in its ability to allow the researcher to gain access to information-rich participants who have direct experiences that yield valuable insights for the research questions. As for the snowball sampling, this technique was employed during the main study. It enabled the researcher to take advantage of social networks by asking the first set of interviewees to nominate other individuals with required qualifications who may be willing to be interviewed (Emmel, 2013).

As a result, seven interviewees were approached directly by the researcher herself through the purposive sampling, and the rest were reached via recommendations from other interviewees. This study achieved a good balance between respondents who had never visited Thailand (twelve) and those who had visited Thailand (twelve). Of 24 respondents, 16 were female and all the respondents were aged 19-48 years old. For those who had visited Thailand before, four had visited only once. The 
demographic profiles of each group of respondents were displayed in Table 2 and Table 3 below.

Table 2. Profiles of respondents who had not visited Thailand

\begin{tabular}{llllll}
\hline Name & Gender & Age & $\begin{array}{l}\text { Marital } \\
\text { Status }\end{array}$ & Education & Occupation \\
\hline NV1 & M & 37 & Single & Master's degree & PhD student \\
NV2 & F & 38 & Married & Bachelor's degree & Housewife \\
NV3 & M & 22 & Single & High school & Student \\
NV4 & F & 21 & Single & High school & Student \\
NV5 & F & 29 & Married & Master's degree & Engineer \\
NV6 & M & 32 & Married & Master's degree & Hotel employee \\
NV7 & M & 19 & Single & High school & Student \\
NV8 & F & 34 & Married & Bachelor's degree & Self-employed \\
NV9 & F & 48 & Married & Doctoral degree & Lecturer \\
NV10 & M & 32 & Single & Bachelor's degree & Doctor \\
NV11 & F & 34 & Married & Master's degree & PhD student \\
NV12 & F & 26 & Single & Bachelor's degree & Self-employed \\
\hline
\end{tabular}

Table 3. Profiles of respondents who had visited Thailand

\begin{tabular}{|c|c|c|c|c|c|c|c|}
\hline Name & Gender & Age & $\begin{array}{l}\text { Marital } \\
\text { Status }\end{array}$ & Education & Occupation & $\begin{array}{l}\text { Frequency of } \\
\text { visit }\end{array}$ & $\begin{array}{l}\text { Travelling } \\
\text { with }\end{array}$ \\
\hline VT1 & F & 19 & Single & High school & Student & Once & A friend \\
\hline VT2 & M & 43 & Married & Master's & PhD student & Twice & Family \\
\hline VT3 & $\mathrm{F}$ & 38 & Single & Master's & Lecturer & Three times & Family \\
\hline VT4 & F & 48 & Married & Bachelor's & Business owner & Once & Friends \\
\hline VT5 & M & 38 & Married & $\begin{array}{l}\text { Doctoral } \\
\text { degree }\end{array}$ & $\begin{array}{l}\text { Government } \\
\text { officer }\end{array}$ & Once & Family \\
\hline VT6 & M & 37 & Married & Bachelor's & Master's student & Four times & Family \\
\hline VT7 & $\mathrm{F}$ & 24 & Single & Bachelor's & Self-employed & Twice & Friends \\
\hline VT8 & F & 25 & Single & Bachelor's & Hotel employee & Once & A friend \\
\hline VT9 & $\mathrm{F}$ & 24 & Single & Bachelor's & Travel agent & Twice & Family \\
\hline VT10 & $\mathrm{F}$ & 36 & Married & Master's & $\begin{array}{l}\text { Government } \\
\text { officer }\end{array}$ & Three times & Friends \\
\hline VT11 & $\mathrm{F}$ & 33 & Married & Bachelor's & Business owner & Twice & Friends \\
\hline VT12 & $\mathrm{F}$ & 31 & Single & Master's & $\begin{array}{l}\text { Computer } \\
\text { consultant }\end{array}$ & Twice & Family \\
\hline
\end{tabular}

Topics of discussion in the interviews were designed around the three dimensions of Thailand's image (i.e. cognitive, affective, and conative), as well as the factors leading the respondents to hold such images (see Table 1 above). The researcher encouraged all the respondents to freely express their opinion and share their truthful views of Thailand as a destination, both positive and negative. All interviews were carried out online through Google Meet and were recorded for data collection after obtaining the written consent of respondents. Each interview lasted about 40-75 minutes. All the interviewees were ensured of the anonymity and confidentiality of their information through the use of pseudonyms (VT is used for visitors to Thailand whereas NV is for non-visitors). 
The interviews were transcribed by the researcher, and the transcriptions were manually analyzed using thematic analysis, following the stages suggested by Braun and Clarke (2006). After transcribing the interviews, the researcher repeatedly read the data in order to familiarize herself with them and search for meaning and patterns. She took notes and marked ideas for initial coding as well as collating relevant data extracts together within each code. These codes were developed based on the main points and common meanings that recurred throughout the data. For example, when a respondent stated 'I always think about Thai food and Thai temples when I visit Thailand' (VT1), the researcher coded this as 'local cuisine' and 'tourism attractions and activities'. Then, the researcher reviewed all the identified codes and sorted them into potential themes. All the relevant data extracts were collated into each theme. Then, all the identified themes were reviewed, together with the collated data extracts. A candidate thematic map was then created, and the sub-themes were also developed to give structure to a large theme. The candidate thematic map was checked and revised to ensure that it accurately represented the meaning of the data as a whole. The names of the themes were given based on the essence of each theme or what story it tells. The researcher also compared the names of these themes to those used in previous related literature.

\section{RESULTS}

This section categorises the findings based on the three main components of destination image (cognitive, affective, and conative). Factors influencing the destination image formation of the respondents are also presented and discussed. This section also intends to reflect the respondents' 'true voice', and therefore interviewees are quoted verbatim, referred to by pseudonyms.

\section{Cognitive Images}

Based on the data analysis, seven attributes representing the cognitive images of Thailand were identified: local cuisine; tourist attractions and activities; local people; political issues; tourist facilities and infrastructure; and lady boys. All these attributes were mentioned by the respondents who had visited Thailand, whereas the non-visitors only mentioned local cuisine, tourist attractions and activities, and lady boys. 


\section{Local cuisine}

Local food, snacks, desserts, and fruits, especially street food, were the most frequently mentioned attribute by all respondents from both groups and was a 'must-do' activity for many respondents from both groups. The majority of the respondents also stated that the reputation of Thai cuisine as cheap, varied, and deliciousness was the main motivator making them want to visit Thailand. Many non-visitors mentioned the recommendations of bloggers, reviewers, media, and/or friends to try famous local food, snacks, desserts, and fruits.

For both groups, frequently mentioned food included Phad Thai (stirfried noodles), Som Tam (green papaya salad), Tom Yam Kung (spicy prawn soup), durians, and coconuts. However, the visitors' perceptions of Thai cuisine were found to be much more detailed and specific than those of nonvisitors, as they could explain the taste, look, and price of food/fruit they had tried (although some visitors could not remember the names of some dishes). For example, VT3 said that 'I really like Tom Yam Kung although it is a bit spicy.... It has a lot of Thai herbs in the soup which makes it unique and very tasty'; and VT7 who stated that 'I ate a lot of durian during that trip. The smell and taste is so good, and the price is not expensive.'

Different experiences of Thai street food were shared by the majority of visitors. They describe it as authentic, freshly cooked, novel, tasty, inexpensive, and an insight into local ways of life and eating habits. Many visitors also stated that having authentic Thai culinary experiences of street food was their key motivation to visit Thailand. For example, VT3 stated that 'I always wanted to have the experience of Thai street food, and it was the main reason for visiting Thailand'. Similar findings were also highlighted by Cifci et al. (2021).

Although local food and fruits were highly praised by the respondents, three visitors who said they liked Thai cuisine also had concerns about food sold by hawkers, street food vendors or in traditional markets, in terms of hygiene, sanitation, cleanliness, and quality. For example, VT3 said; 'I found that most of the street food did not have anything to cover it, so you could see flies on the food'. However, these concerns were not shared by non-visitors.

\section{Tourist attractions and activities}

Tourist attractions were also cited by all the respondents from both groups, and all responses were positive. Thailand's tourist attractions were praised 
for their diversity and beauty. Both cultural and natural tourist sites were mentioned by both groups. Non-visitors focused on iconic places in Bangkok and famous seaside cities that they wished to visit. Interestingly, responses from some non-visitors were quite detailed, including the locations, and specific features of certain tourist sites, even though they had not visited these places. These non-visitors explained that they had read many reviews from travel blogs and other online user-generated content (UGC). However, many of these non-visitors were not able to remember the exact names of the sites, especially the names of Buddhist temples. For example, NV4 said, 'I had seen from TV documentaries that there were many magnificent Buddhist temples in Bangkok. I don't remember their names, but one of them is the temple with a very big reclining Buddha image'.

For visitors, their impressions were also centered around iconic features of Bangkok, such as Buddhist temples including the Temple of the Emerald Buddha, the Temple of Dawn, and the Temple of the Reclining Buddha Image, as well as famous seaside cities including Pattaya, Phuket, and Krabi. These places were noted by many visitors as must-visit sites for first-time visitors. The Buddhist temples were highly praised for their extravagant, magnificent and unique architectural style, and decoration, while the seaside cities were complimented in terms of their beautiful beaches, clear sea-water, variety of beach activities, and water sports for tourists. Some visitors mentioned other lesser-known cities favourably, such as Kanchaburi, Phra Nakhon Si Ayutthaya, and Sukhothai. However, some visitors could not remember names and/or precise descriptions of some places.

In terms of activities, one non-visitor expressed a willingness to learn Thai boxing, whereas two non-visitors would like to get a Thai massage and felt these activities were must-do things if they visited Thailand. Thai massage was also mentioned by one visitor as something she would definitely do again if she revisits Thailand.

In addition, shopping was also mentioned as one of the most interesting tourist activities to do in Thailand. More than half of respondents from both groups mentioned that Thailand was a very good place for shopping. In their view, products in Thailand were cheap and varied, including many attractive products including tourist souvenirs (e.g. magnets, hats, folding fans, etc.), clothes, accessories, appliances, food, and snacks. The respondents were able to name many shopping places in Bangkok such as Chatuchak Weekend Market, Pratunam, Platinum Fashion Mall, Central World, Siam Square, and Asiatique. 


\section{Local people}

The cognitive images concerning local people were expressed by only respondents who had visited Thailand. In general, these respondents had very positive views of Thai people. They said that based on their own encounters with the locals, they were very impressed by hospitality, friendliness, and warmness of these people. Below are some comments shared by the respondents:

'I was impressed by friendliness, care, and kindness of Thai people. There was one time when my friend and I were trying to find a direction to the nearest skytrain station, one girl offered to help us. She could speak some Mandarin ... She was very nice and kind.' (VT1)

However, three respondents had negative views of local people, whom they said had been very rude. VT7 stated that her friends and she were once harassed by a group of teenagers on the street. Although she could not understand what these people said, she could guess from their actions that these people were mocking them, and the incident made her feel ashamed.

\section{Political issues}

Political issues in Thailand were found to be connected to a negative image of the country for respondents. This attribute was mentioned by two respondents who had visited Thailand, who described an encounter with an anti-government protest during a trip to Bangkok in January 2019. One respondent visited Thailand independently with two friends, while the other was on an organised group tour. They similarly noted that they were unfortunate to visit Thailand at that time, and the protest negatively affected their holiday, as the protesters blocked important spots and streets in Bangkok. VT10 stated that she saw thousands of people gathering on major spots in Bangkok, and many of these people shouting and holding anti-government banners. She was scared to travel to tourist attractions situated near the protest sites.

\section{Tourist facilities and infrastructure}

This was mentioned only by respondents who had visited Thailand, who spoke of local transportation and accommodation. Regarding local transportation, the respondents' perceptions were extremely negative, describing transport in Bangkok and between Bangkok and other cities. Specifically, the lack of orderliness and convenience was highly criticised. 
They found that there were very limited skytrains and subways in Bangkok, that did not go to the main tourist attractions such as the Royal Palace and the Temple of the Emerald Buddha, and the Temple of Dawn. There were only buses going to these places. Travelling by bus in Bangkok was not easy for foreigners because all the signs were in Thai, and the bus drivers and the ticket takers could not speak English nor Chinese. VT4 remarked that 'My friends and I tried to use a public bus to go to the Royal Palace, but we had to change our mind to take a taxi after trying to figure it out which bus to take. The bus system in Bangkok is very confusing. Everything is in Thai.'

The inconvenience of public transportation between Bangkok and other cities was also discussed by two respondents. They stated that the train system in Thailand was very outdated and inconvenient and that they had taken coaches or flights. Traffic in Bangkok was also a source of complaint for many respondents, who were shocked by the congestion and were annoyed to be stuck on the road.

As for accommodation, three respondents shared similar views that Thailand was a perfect tourist destination in terms of accommodation for tourists because there was a great range of accommodations, from very well-known branded hotels to budget guesthouses; prices were affordable, and hotel staff very professional.

\section{Lady boys}

Two non-visitors and five visitors mentioned the lady boys. They found that, compared to other countries, Thailand was much more open to LGBT culture. Below are some comments illustrating opinions of the respondents on this attribute:

'I was shocked when my friend who visited Thailand showed me pictures of lady boys who were performers of the show in Thailand. I could not believe that they were men. They really looked like girls, and they were more beautiful than many girls I had seen' (NV12).

'I think Thailand is the country that has the highest number of lady boys in the world. You can see them everywhere in Thailand. I am not exaggerating. They dressed in female costume, and acted just like women. Many of them looked really like real women' (VT2).

\section{Affective Images}

Non-visitors used a limited range of terms to describe their feelings towards Thailand, but they all demonstrated positive feelings, such as 'joyful', 
'excited', 'relaxed', 'fun', and 'calm'. Visitors were more mixed. Positive terms included 'happy', 'relaxed', 'fun', 'excited', 'surprised' and 'impressed', whereas negative feelings were 'scared', 'worried', 'upset', 'annoyed', 'tired', and 'ashamed'.

The data analysis shows that the respondents described their feelings based on both the overall expectations of a trip to Thailand (for non-visitors) or the overall experiences of visiting Thailand (for visitors), and on specific attributes such as local cuisine, tourist attractions, local transportation, and political issues. The overall expectations/experiences of the respondents were reported to be only positive, while those attached to specific attributes were mixed. Examples of opinions of the non-visitors regarding their overall expectations include: 'I am very excited to visit Thailand' (NV2); and 'I think Thailand is a relaxed country' (NV4). As for the visitors, examples of their comments on their overall experiences of visiting Thailand include: ' $I$ had a very impressive and fun experiences' (VT9); and 'It was a mix of relaxing and exciting' (VT12). The comments on specific attributes are as follows: 'I was very excited to see a variety of street food' (VT3); 'I was very annoyed to be stuck on the road because of the heavy traffic in Bangkok' (VT8); and 'My friend and I were very ashamed when we were harassed by local teenagers' (VT7).

Moreover, it was interesting to find that some visitors compared their feelings before and during the trip and mentioned that their feelings towards specific attributes had changed. For example, VT8 stated that 'I was very surprised by the taste and price of Thai food. I assumed that Thai food might be too spicy, but I found that they were very tasty... These exceeded my expectation'; and VT 9 said, 'Before visiting, I didn't imagine that Thai temples would be very beautiful and elegant. The style and decorations were more than what I expected.'

\section{Conative Images}

Both groups of the respondents had mixed intentions to visit/revisit Thailand. For the non-visitors, although all of them expressed their intent to visit Thailand, their plan varied from vague and uncertain, to clear intentions to visit in the next few months. For those who were uncertain, their reasons were mainly related to their unreadiness in terms of time and budget for a trip. For the visitors, ten respondents showed willingness to revisit Thailand, for the following reasons: expecting that a further trip would be as joyful as previous trips; a desire to take family members or friends to Thailand; a desire to do things they found attractive and interesting again; and a desire to visit new places, do new activities, and/or try more foods. 
It was interesting that some visitors who mentioned negative experiences/feelings were still keen to visit Thailand again. They explained that, based on their overall perception, their positive experiences/feelings on some specific attributes outweighed the negatives, and they believed the problems they faced during the trip could be avoided. For example, VT7 who had been harassed by local teenagers said that 'Oh, I will definitely visit Thailand again... I believe that not every Thai people are not like those people who harassed me'; and VT10, who mentioned about her negative feelings about the anti-government protest, noted, 'Next time, I would definitely check before whether there is a protest in Bangkok or not, or if there is, I will visit other cities in Thailand'.

It was also found that revisiting Thailand was unlikely for two visitors, even though they had very positive perceptions of Thailand both in terms of their cognitive image and affective image. These respondents explained that they wanted to explore new countries, instead of returning to a destination that they had already visited.

\section{Factors Influencing Destination Image Formation}

The data analysis showed that a variety of factors influenced the destination image formation of the respondents. For non-visitors, factors used to form their images of Thailand included various information sources (i.e. wordof-mouth from friends/family members, online UGC, travel blogs, promotional materials of tourism-related organisations, tour companies, and/or travel agencies, TV documentaries, movies, TV dramas, magazines, guidebooks, websites, and social media). Among these, word-of-mouth from friends/family members, online UGC, and travel blogs were found to be the most trusted sources. Interestingly, online UGC in a form of clips posted on social media was found to make non-visitors more familiar with many attributes of Thailand, thereby developing their cognitive, affective, and conative images. Many non-visitors similarly stated that these clips helped them see how Thailand really looks. NV1 said that 'I felt like I was really travelling in Thailand with the presenters'. The responses demonstrate their confidence in the images of Thailand they held, as they could name locations, and interesting features of many local dishes and tourist sites correctly.

For visitors, on-site experiences, including visiting places, doing activities, having interactions with people, using tourism facilities and infrastructure, served as the main factors in their destination image formation. The data showed that all the visitors based their perceptions on 
past experiences of visiting Thailand. The respondents explained that direct experiences and encounters increased their knowledge of and familiarity with Thailand, and they felt more informed compared to their pre-trip stage.

\section{DISCUSSION AND CONCLUSIONS}

The analysis shows that there are differences in the perceptions of Thailand's image between non-visitors and visitors. In terms of their cognitive images, non-visitors mentioned fewer attributes of Thailand in their perceptions than visitors did. Many of these attributes were also reported in previous studies. For example, local cuisine, tourist attractions and activities, local people, and tourist facilities and infrastructure were reported as relevant by Rittichainuwat et al. (2001) and Henkel et al. (2006), and all of these attributes, except tourist facilities and infrastructure, were reported by Tapachai and Waryszak (2000). Among the reported cognitive images, anti-government protests and lady boys were not mentioned in previous studies, which may be because previous studies employed a quantitative research approach using a list of pre-determined attributes that did not include these aspects. Moreover, the time period in which the research was conducted could possibly affect the findings. This current research was conducted long after the majority of this previous research, and therefore perceptions of the respondents may have changed, denoting the dynamic nature of destination image as suggested by existing literature (Chen, 2019; Kong et al., 2015; Stylidis \& Cherifi, 2018).

The findings on cognitive images also indicate differences between non-visitors and visitors in terms of positive and negative views. Nonvisitors were found to have only positive images on all of the mentioned attributes, whereas visitors expressed both positive and negative views. Specifically, visitors showed mixed perceptions on local cuisine, local people, and tourist facilities and infrastructure; only positive views on tourist attractions and activities, and lady boys; and only negative opinions on political issues. Similar patterns of findings were detected for affective images. Non-visitors expressed only positive feelings towards Thailand and used a very limited range of terms to illustrate them, whereas visitors had more varied feelings and vocabularies.

Lastly, for conative images, both groups reported a mixed intention to visit/revisit Thailand. All non-visitors intended to visit, but their plan varied from being uncertainty to having a definite plan. The study found that positive cognitive and affective evaluations of the images of Thailand 
did not always lead respondents to visit/revisit the country, and negative cognitive and affective images did not make the respondents avoid visiting the country either. This challenges existing literature (Afshardoost \& Eshaghi, 2020; Agapito et al., 2013; Peña et al., 2012) that argues that individuals' assessment of cognitive and affective images influences their conative image or intention to visit/revisit the destination. Rather, this study argues that although the cognitive and affective images were taken into account when the respondents decided to visit/revisit Thailand, such a decision depended on other factors, such as their readiness in terms of time, budget and motivations.

The above findings show that destination image is complex, multidimensional, relativistic, and dynamic, which supports existing literature (Gallarza et al., 2002; Martín \& Rodríguez del Bosque, 2008; Stylidis \& Cherifi, 2018). Complexity and multiplicity in images of Thailand are evident from the responses that identify a number of attributes and have mixed opinions on these attributes, as well as various feelings about whether to visit/revisit the country. This study adds additional insight, finding that some respondents held both positive and negative images on specific attributes. For example, three respondents who had visited Thailand were excited to find varied street food and fruits in Thailand, but were also worried in terms of hygiene and cleanliness. It can be concluded that the visitors can have both positive and negative opinions (cognitive image) and feelings (affective image) on a certain attribute.

With regard to the relativistic nature of the image of Thailand, the findings agree with the studies of Kotler and Gartner (2002) and Stylidis and Cherifi (2018), that notable differences exist between non-visitors and visitors in terms of the clarity and details of their perceptions. Non-visitors' perceptions of Thailand, mainly based on secondary sources of data, were relatively vague and brief, whereas those of visitors appeared to be more specific and detailed, resulting from previous trips. These findings also support existing literature (Smith et al., 2015; Song \& Hsu, 2013; Stylidis \& Cherifi, 2018) that actual visits enable individuals to have first-hand encounters with people, tourist infrastructure, and facilities, which then are significant in forming their images of Thailand, as they had greater knowledge of and familiarity with the country.

Moreover, this study provides additional knowledge of the phenomenon of destination image in terms of the concrete in the perceptions of non-visitors and visitors. This study argues that non-visitors' perceptions of a destination are not always vague and brief, as some non- 
visitors had quite detailed perceptions on many attributes of Thailand due to their exposure to reviews from travel blogs and clip videos about Thailand, denoting the important role of these factors. For visitors, the study found that although the cognitive perceptions of the visitors were found to be more concrete and detailed than those of the non-visitors, some visitors could not provide precise descriptions of some attributes (e.g. the names of foods or the locations of certain tourist attractions). This means that vagueness in the perceptions of some destination attributes could still exist among some visitors, despite their experience of a destination. This should be addressed by destination marketers because vagueness may affect negatively the overall image of a destination.

In terms of the dynamic features of destination image, changes in cognitive and affective images of the visitors were evident, which is in line with existing literature (Chen, 2019; Kong et al., 2015; Stylidis \& Cherifi, 2018). In this study, this characteristic of destination image was prominent in the group of visitors as their responses indicated comparison between their expectations before visiting and their real experiences during the trip. They spoke of being surprised and having their expectations exceeded.

Moreover, the findings of this study support existing literature (Agapito et al., 2013; Baloglu \& McCleary, 1999a; Li et al., 2010) that argues that affective images are influenced by individuals' evaluations of their cognitive images, and therefore they are formed as a function of cognitive images. This study found that these two dimensions had hierarchical relations, with cognitive images serving as preceding factors, whereas affective images were the consequences of cognitive images. In order words, both non-visitors and visitors expressed their feelings based on their evaluations of specific attributes. However, this study also found that respondents from both groups also described their feelings based on their overall expectations of a trip to Thailand (non-visitors) or the overall experience of visiting Thailand (visitors).

In relation to the factors influencing the formation of the image of Thailand, although the findings of this study are similar to previous studies stating that information sources (Pan \& Tsang, 2014; Stylidis \& Cherifi, 2018; Terzidou et al., 2018) and on-site experiences (Smith et al., 2015; Song \& Hsu, 2013; Stylidis et al., 2017) are important factors, this study also reported the role of these factors in each group of respondents. Information sources, especially word-of-mouth from friends/family members, travel blogs and UGC were found to play an important role in formulating the images of Thailand for non-visitors, which is in agreement with 
Gholamhosseinzadeh et al. (2021) and Xu et al. (2021), whereas on-site experiences represented the main factors for destination image formation in visitors. In addition, this study found that non-visitors played attention to the reliability of the information sources in the hope of gaining a more accurate view of Thailand.

This study reinforces the knowledge on destination image, especially in the context of Thailand by adding empirical evidence to existing literature. First, it employed a qualitative research approach to investigate the topic. This study not only confirms the argument made in existing quantitative literature that destination image is complex, multidimensional, relativistic, and dynamic, but it also reports on 'how', and 'why' relating to each of these features. Secondly, it is one of very few studies examining the image of Thailand from Chinese people's perspectives, and the first study that compares Chinese non-visitors' and visitors' perceptions.

Third, this study makes an argument in terms of relationship between cognitive, affective, and conative dimensions of the destination image. Previous studies (Afshardoost \& Eshaghi, 2020; Agapito et al., 2013; Peña et al., 2012) report the hierarchical relationship between these three dimensions and argue that cognitive and affective images influence the conative dimension. This study shows that individuals' evaluations of cognitive images and affective images do not always influence their conative image or their intention to visit/revisit the destination. Some individuals who had positive cognitive and affective images of Thailand did not intend to visit Thailand, and some respondents who had negative views and/or feelings said that, nevertheless, they had a plan to visit Thailand in the near future. This study argues that conative images held by individuals may partly depend on the evaluations of their cognitive and affective images, but it is also affected by other factors, including their readiness to travel in terms of time and budget, and motivations.

Lastly, this study extends the knowledge on the role of factors in destination image formation by arguing that, in the digital age, reviews on travel blogs and UGC play an important role in the non-visitors' destination image formation process. While other factors, as reported in existing literature, still have a role in such processes, these two factors appear to dominate, as they are reliable in the views of these individuals, enable the non-visitors to become familiar with the destinations before visiting, and help them to form a more accurate image of the destination. 
The study has practical implications for tourism policy-makers, destination planners, and destination marketing organisations (DMOs) of Thailand. In-depth understanding of the images of the country held by Chinese people, who are its main target market, is a key for success in the development and marketing of the country. First, knowledge on their positive and negative opinions on and feeling towards certain attributes of the country can help policy-makers and destination planners to assess strengths and weaknesses of Thailand based on the views of this market, and use such insight to develop strategic plans and communication strategies that focus on informing the Chinese market on practices and measures that have been implemented to eliminate or minimise risks in the country as well as marketing strategies aiming to strengthen positive aspects of the country. For example, as reported in this study that local food and fruits, especially street food, were highly praised by visitors and were also their key motivation for visiting Thailand. However, some visitors were concerned about its hygiene, cleanliness, and the quality. With this knowledge in mind, DMOs should develop standards and measures aiming to improve these issues. The study by Cifci et al. (2021) reports that local guides play a significant role in promoting Thai street food and reducing perceived risks concerning its hygiene and cleanliness among visitors by informing them about Thai street food (e.g. background information, cooking techniques, interesting facts, recipes, etc.), taking them to clean settings offering street food, trying food first before visitors to reassure them that it was safe, and recommending food to visitors with dietary needs such as allergies. Such actions by local guides can significantly enhance the visitors' experiences and help them overcome the fear or perceived risks of Thai street food. Therefore, the DMOs should cooperate with local guides in promoting local foods within this market.

In addition, knowledge on factors playing an important role in the formation of destination image of Thailand can be beneficial for tourism practitioners as well. As this study identified the important role of reviews from travel blogs and UGC in helping Chinese non-visitors become familiar with Thailand, DMOs should aim their marketing efforts more at these communication tools. Moreover, as mentioned earlier, vagueness in the perceptions of some destination attributes still exists among some visitors, despite their actually visiting Thailand. Such vagueness may damage the image held by non-visitors because these visitors may describe Thailand inaccurately to their friends/family members who have never visited Thailand. It is agreed that word-of-mouth of previous visitors is a major factor in the formulation of destination images for non-visitors, so vague 
information given by previous visitors may be problematic. Therefore, destination planners and DMOs should develop strategies to enhance onsite experiences of visitors in order to make their experiences memorable. Cooperation from local tourist guides and implementation of effective tourism interpretation techniques can serve as the main tools in this regard.

With regard to the limitations of this study, two main limitations were identified. First, as this study employed qualitative research, with the findings arising from a small number of respondents obtained via nonprobability sampling, there is a limitation in terms of generalisability. However, it is the main aim of this study to gain rich and in-depth insights of the issue being investigated, rather than to generalise its findings. Secondly, the findings of this research were based only on the data gained from Chinese respondents who could speak either English or Thai, due to the researcher's limited ability to communicate in Chinese language. As a result, some possibly different or additional data which would have been obtained from non-English speaking Chinese respondents were omitted.

To address the limitations acknowledged above, future research on Thailand's image should include non-English Chinese respondents to provide a more complete picture of the image of the country in the perceptions of Chinese people. Moreover, to create a competitive advantage for any destination, understanding perceptions of non-visitors/visitors on that particular destination is not sufficient, therefore future research on comparison of the visitors' perceptions of Thailand's image in relation to its main competitors is recommended.

\section{ACKNOWLEDGEMENT}

The author thanks Woosong University for its 2021 Woosong University inschool academic research grant.

\section{REFERENCES}

Afshardoost, M., \& Eshaghi, M. S. (2020). Destination image and tourist behavioural intentions: A meta-analysis. Tourism Management, 81, 104154. https://doi.org/10.1016/j.tourman. 2020.104154

Agapito, D., Valle, P., \& Mendes, J. (2013). The cognitive-affective-conative model of destination image: A confirmatory analysis. Journal of Travel E Tourism Marketing, 30(5), 471-481. https://doi.org/10.1080/10548408.2013.803393

Ahmad, A., Jamaludin, A., Zuraimi, N. S. M., \& Valeri, M. (2020). Visit intention and destination image in post-Covid-19 crisis recovery, Current Issues in Tourism. 24(17), 2392-2397. https://doi.org/10.1080/13683500.2020.1842342 
Alcocer, N. H., \& Ruiz, V. R. L. (2020). The role of destination image in tourist satisfaction: the case of a heritage site. Economic Research-Ekonomska Istraživanja, 33(1), 24442461. https://doi.org/10.1080/1331677X.2019.1654399

Alvarez, M. D., \& Campo, S. (2014). The influence of political conflicts on country image and intention to visit: A study of Israel's image. Tourism Management, 40, 70- 78. https://doi.org/10.1016/j.tourman.2013.05.009

Ashworth, G., \& Kavaratzis, M. (2009). Beyond the logo: Brand management for cities. Journal of Brand Management, 16(8), 520-531. https://doi.org/10.1057/palgrave. bm. 2550133

Baloglu, S. (1999). A path analytic model of visitation intention involving information sources, socio-psychological motivations, and destination image. Journal of Travel and Tourism Marketing, 8(3), 81-91. https://doi.org/10.1300/J073v08n03_05

Baloglu, S. (2001). Image variations of Turkey by familiarity index: Informational and experiential dimensions. Tourism Management, 22(2), 127-133. https://oi.org/ 10.1016/S0261-5177(00)00049-2

Baloglu, S., \& McCleary, K. W. (1999a). A model of destination image formation. Annals of Tourism Research, 26(4), 868-897. https://doi.org/10.1016/S0160-7383(99)00030-4

Baloglu, S., \& McCleary, K. W. (1999b). US international pleasure travelers' images of four Mediterranean destinations: A comparison of visitors and nonvisitors. Journal of Travel Research, 38(2), 144-152. https://doi.org/10.1177/004728759903800207

Braun, V., \& Clarke, V. (2006). Using thematic analysis in psychology. Qualitative Research in Psychology, 3(2), 77-101. https:// doi.org/10.1191/1478088706qp063oa

Carballo, M. M., Araña, J. E., León, C. J., \& Moreno-Gil, S. (2015). Economic valuation of tourism destination image. Tourism Economics, 21(4), 741-759. https://doi.org/10. $5367 /$ te.2014.0381

Carey, M. (2013). The social work dissertation: Using small-scale qualitative methodology. $2^{\text {nd }} e d$. Berkshire: Open University Press.

Chen, Z. (2019). A qualitative pilot study exploring tourists' pre-and post-trip perceptions on the destination image of Macau. Journal of Travel \& Tourism Marketing, 36(3), 330-344. https://doi.org/10.1080/10548408.2018.1541777

Chi, C. G. Q., \& Qu, H. (2008). Examining the structural relationships of destination image, tourist satisfaction and destination loyalty: An integrated approach. Tourism Management, 29(4), 624-636. https://doi.org/10.1016/j.tourman.2007.06.007

Cifci, I., Atsiz, O., \& Gupta, V. (2021). The street food experiences of the local-guided tour in the meal-sharing economy: The case of Bangkok. British Food Journal, 123(12), 4030-4048. https://doi.org/ 10.1108/BFJ-01-2021-0069

Echtner, C. M., \& Ritchie, J. R. B. (1991). The meaning and measurement of destination image. Journal of Tourism Studies, 2(2), 2-12.

Emmel, N. (2013). Sampling and choosing cases in qualitative research: A realist approach. London: Sage.

Gallarza, M. Saura, G., \& García, H. C. (2002). Destination image: Towards a Conceptual Framework. Annals of Tourism Research, 29(1), 56-78. https://doi.org/10.1016/ S01607383(01)00031-7

Gartner, W. C., \& Hunt, J. D. (1987). An analysis of state image change over a twelve-year period (1971-1983). Journal of Travel Research, 26(2), 15-19. https://doi.org/10. $1177 / 004728758702600204$

George, B. P., \& George, B. P. (2004). Past visit and the intention to revisit a destination: Place attachment as the mediator and novelty seeking as the moderator. The Journal of Tourism Studies, 15(2), 51-66. 
Gholamhosseinzadeh, M. S., Chapuis, J., \& Lehu, J. (2021). Tourism netnography: how travel bloggers influence destination image. Tourism Recreation Research. https//doi.org/10.1080/02508281.2021.1911274

Glover, P. (2009). Celebrity endorsement in tourism advertising: Effects on destination Image. Journal of Hospitality and Tourism Management, 16(1), 16-23. https://doi.org/10.1375/jhtm.16.1.16

Hernández-Mogollón, J. M., Duarte, P. A., \& Folgado-Fernández, J. A. (2018). The contribution of cultural events to the formation of the cognitive and affective images of a tourist destination. Journal of Destination Marketing $\mathcal{E}$ Management, 8, 170-178. https://doi.org/10.1016/j.jdmm.2017.03.004

Henkel, R., Henkel, P., Agrusa, W., Agrusa, J., \& Tanner, J. (2006). Thailand as a tourist destination: Perception of International Visitors and Thai residents. Asia Pacific Journal of Tourism Research, 11(3), 269-287. https://doi.org/10.1080/ 10941660600753299

Hughes, H. L., \& Allen, D. (2008). Visitor and non-visitor images of Central and Eastern Europe: A qualitative analysis. International Journal of Tourism Research, 10(1), 2740. https://doi.org/10.1002/jtr.622

Jennings, G. (2011). Tourism research. $2^{\text {nd }}$ ed. Milton, Queensland: John Wiley\& Sons.

Kasikorn Research Center. (2018). Industry Outlook Analysis. Retrieved June 10, 2021, from https://kasikornresearch.com/ en/ analysis/k-econ/business/Pages/z2925.aspx

Kasikorn Research Center. (2019). Industry Outlook Analysis. Retrieved June 10, 2021 from https://kasikornresearch.com/ en/analysis/k-econ/business/Pages/z2963.aspx

Kavaratzis, M., \& Hatch, M. J. (2013). The dynamics of place brands: An identity-based approach to place branding theory. Marketing Theory, 13(1), 69-86. https://doi.org/ $10.1177 / 1470593112467268$

Khan, M. J., Chelliah, S., \& Ahmed, S. (2017). Factors influencing destination image and visit intention among young women travellers: Role of travel motivation, perceived risks, and travel constraints. Asia Pacific Journal of Tourism Research, 22(11), 1139-1155. https://doi.org/10.1080/10941665.2017.1374985

Kim, S. (2012). Audience involvement and film tourism experiences: Emotional places, emotional experiences. Tourism Management, 33(2), 387-396. https://doi.org/ 10.1016/j.tourman.2011.04.008

Kim, H., \& Chen, J. (2016). Destination image formation process: A holistic model. Journal of Vacation Marketing, 22(2), 154-166. https://doi.org/10.1177/1356766715591870

Kim, H., \& Richardson, S. L. (2003). Motion picture impacts on destination images. Annals of Tourism Research, 30(1), 216-237. https://doi.org/10.1016/S0160-7383(02)00062-2

Kladou, S., \& Mavragani, E. (2015). Assessing destination image: An online marketing approach and the case of TripAdvisor. Journal of Destination Marketing $\mathcal{E}$ Management, 4(3), 187-193. https://doi.org/ 10.1016/j.jdmm.2015.04.003

Konecnik, M., \& Ruzzier, M. (2006). The influence of previous visitation on customer's evaluation of a tourism destination. Managing Global Transitions, 4(2), 145-165.

Kong, W. H., Du Cros, H., \& Ong, C. E. (2015). Tourism destination image development: A lesson from Macau. International Journal of Tourism Cities, 1(4), 299-316. https://doi.org/10.1108/IJTC-08-2014-0016

Kotler, P., \& Gertner, D. (2002). Country as brand, product, and beyond: A place marketing and brand management perspective. Journal of Brand Management, 9(4), 249-261. https://doi.org/10.1057/palgrave.bm.2540076 
Krider, R. E., Arguello, A., Campbell, C., \& Mora, J. D. (2010). Trait and image interaction: In ecotourism preference. Annals of Tourism Research, 37(3), 779-801. https://doi.org/ 10.1016/j.annals.2010.01.009

Li, M., Cai, L., Lehto, X., \& Huang, J. (2010). A missing link in understanding revisit intention - The role of motivation and image. Journal of Travel \& Tourism Marketing, 27(4), 335-348. https://doi.org/10.1080/10548408.2010.481559

Magnusson, P, Krishnan, V, Westjohn, S. A., \& Zdravkovic, S. (2014). The spillover effects of prototype brand transgressions on country image and related brands. Journal of International Marketing, 22(1), 21-38. https://doi.org/10.1509/jim.13.0068

Martín, H. S., \& Rodríguez del Bosque, I. A. (2008). Exploring the cognitive-affective nature of destination image and the role of psychological factors in its formation. Tourism Management, 29(2), 263-277. https://doi.org/10.1016/j.tourman.2007.03.012

Michael, N., James, R., \& Michael, I. (2018). Australia's cognitive, affective and conative destination image: An Emirati tourist perspective. Journal of Islamic Marketing, 9(1), 36-59. https://doi.org/10.1108/JIMA-06-2016-0056

National Statistical Office. (2021). Tourism and Sport Branch. Retrieved June 24, 2021, from http://statbbi.nso.go.th/ staticreport/page/sector/en/17.aspx

Pan, S., \& Tsang, N. (2014). Inducible or not-A telltale from two movies. Journal of Travel and Tourism Marketing, 31(3), 397-416. https://doi.org/10.1080/10548408.2014. 883345

Papadimitriou, D., Apostolopoulou, A., \& Kaplanidou, K. (2015). Destination personality, affective image, and behavioural intentions in domestic urban tourism. Journal of Travel Research, 54(3), 302-315. https://doi.org/10.1177/0047287513516389

Patton, M. Q. (2014). Qualitative research E evaluation methods: Integrating theory and practice. London: Sage.

Peña, A. I. P., Jamilena, D. M. F., \& Molina, M. A. R. (2012). Validation of cognitive image dimensions for rural tourist destinations: A contribution to the management of rural tourist destinations. Journal of Vacation Marketing, 18(4), 261-73. https://doi.org/ 10.1177/1356766712449351

Perpiña, L., Camprubí, R., \& Prats, L. (2019). Destination image versus risk perception. Journal of Hospitality \& Tourism Research, 43(1), 3-19. https://doi.org/10.1177/ 1096348017704497

Pike, S., \& Ryan, C. (2004). Destination positioning analysis through a comparison of cognitive, affective, and conative perceptions. Journal of Travel Research, 42(4), 333342. https://doi.org/10.1177/0047287504263029

Promsivapallop, P., \& Kannaovakun, P. (2019). Destination food image dimensions and their effects on food preference and consumption. Journal of Destination Marketing \& Management, 11, 89-100. https://doi.org/10.1016/j.jdmm.2018.12.003

Qu, H., Kim, L. H., \& Im, H. H. (2011). A model of destination branding: Integrating the concepts of the branding and destination image. Tourism Management, 32(3), 465476. https://doi.org/10.1016/j.tourman.2010.03.014

Quintal, V. A., Lee, J. A., \& Soutar, G. N. (2010). Risk, uncertainty and the theory of planned behaviour: A tourism example. Tourism Management, 31(6), 797-805. https://doi.org/10.1016/j.tourman.2009.08.006

Reisinger, Y., \& Mavondo, F. (2005). Travel anxiety and intentions to travel internationally: Implications of travel risk perception. Journal of Travel Research, 43(3), 212-225. https://doi.org/10.1177/0047287504272017

Reisinger, Y., \& Mavondo, F. (2006). Cultural differences in travel risk perception. Journal of Travel $\mathcal{E}$ Tourism Marketing, 20(1), 13-31. https://doi.org/10.1300/J073v20n01_02 
Riscinto-Kozub, K., \& Childs, N. (2012). Conversion of local winery awareness: An exploratory study in visitor vs non-visitor attitude and perception. International Journal of Wine Business Research, 24(4), 287-301. https://doi.org/10.1108/ 17511061211280338

Rittichainuwat, B. N., Qu, H., Brown, T. J. (2001). Thailand's international travel image: Mostly favorable. Cornell Hotel and Restaurant Administration Quarterly, 42(2), 8295. https://doi.org/10.1016/S0010-8804(01)80020-3

Ryan, C., \& Cave, J. (2005). Structuring destination image: A qualitative approach. Journal of Travel Research, 44(2), 143-150. https://doi.org/10.1177/0047287505278991

Smith, W., Li, X., Pan, B., Witte, M., \& Doherty, S. (2015). Tracking destination image across the trip experience with smartphone technology. Tourism Management, 47, 113-122. https://doi.org/10.1016/j.tourman.2014.04.010

Song, H., \& Hsu, C. H. C. (2013). The image of Taiwan as a travel destination: Perspectives from Mainland China. Journal of Travel \& Tourism Marketing, 30(3), 253-271. https://doi.org/10.1080/10548408.2013.774919

Stylidis, D., Belhassen, Y., \& Shani A. (2017). Destination image, on-site experience and behavioural intentions: Path analytic validation of a marketing model on domestic tourists. Current Issues in Tourism, 20(15), 1653-1670. https://doi.org/10.1080/ 13683500.2015.1051011

Stylidis, D., \& Cherifi, B. (2018). Characteristics of destination image: Visitors and nonvisitors' Images of London. Tourism Review,73(1), 55-67. https://doi.org/ 10.1108/TR-05-2017-0090

Tan, W., \& Wu, C. (2016). An investigation of the relationships among destination familiarity, destination image and future visit intention. Journal of Destination $\begin{array}{llll}\text { Marketing } & \mathcal{E} & \text { Management, } & \text { 5(3), }\end{array}$ https://doi.org/10.1016/J.JDMM.2015.12.008

Tapachai, N., \& Waryszak, R. (2000). An examination of the role of beneficial image in tourist destination selection. Journal of Travel Research, 39(1), 37-44. https://doi.org/10.1177/004728750003900105

Terzidou, M., Stylidis, D., \& Terzidis, K. (2018). The role of visual media in religious tourists' destination image, choice and on-site experience: The case of Tinos, Greece. Journal of Travel $\mathcal{E}$ Tourism Marketing, 35(3), 306-319. https://doi.org/10.1080/ 10548408.2017.1304316

World Tourism Organisation. (2019). International Tourism Highlights, 2019 Edition. Retrieved June 24, 2021, from https://www.e-unwto.org/doi/epdf/10.18111/ 9789284421152

World Tourism Organisation. (2021). International Tourism Highlights, 2020 Edition. Retrieved June 24, 2021, from https://www.e-unwto.org/doi/epdf/10.18111/ 9789284422456

Xu, H., Cheung, L. T. O., Lovett, J., Duan, X., Pei, Q., \& Liang, D. (2021). Understanding the influence of user-generated content on tourist loyalty behaviour in a cultural World Heritage Site. Tourism Recreation Research. https://doi.org/10.1080/02508281. 2021.1913022 